\title{
Triphala improves glucose homeostasis by alleviating atherogenic lipids and oxidative stress in human Type 2 diabetes mellitus
}

\author{
Research Article
}

\author{
Nita Singh $^{1}$, Sunil Mahajan ${ }^{1}$, Senthil K Subramani ${ }^{1}$, \\ Dhananjay $\operatorname{Yadav}^{2}$, Lokendra Singh ${ }^{3}, \operatorname{Prasad}_{\text {GBKS }}{ }^{\text {* }}$
}

1. School of studies in Biochemistry, Jiwaji University, Gwalior, Madhya Pradesh-474011, India

2. Department of Internal Medicine, Yonsei University Wonju College of Medicine, Wonju, Korea.

3. DLS, DRDO Hqrs, DRDO Bhawan, New Delhi-110105

\begin{abstract}
Aims: 'Triphala' constituting equal parts of three medicinal dried plant fruits Emblica Officinalis Gaertn., Terminalia chebula Retz. and Terminalia bellerica Gaertn. is an antioxidant rich Ayurvedic formulation. The present study assessed therapeutic as well as protective effects of Triphala on human subjects with Type 2 diabetes mellitus (T2DM) and Impaired glucose tolerance (IGT).

Materials and methods: Triphala at a dose of 5 gms BD was administered to two cohorts viz., IGT, N=20 and T2DM, N=30 consecutively for a period of 12 months. The therapeutic efficacy was assessed quarterly by monitoring blood glucose and lipid levels; the protective effect by monitoring antioxidants level quarterly and DNA damage annually. Toxicity if any, to liver and kidney due to long term administration was assessed quarterly in both cohorts.

Results: Continuous 'Triphala' therapy for 12 months significantly reduced blood glucose $(\mathrm{p} \leq 0.001)$ and lipid levels $(\mathrm{p} \leq 0.05)$ in both the cohorts. Triphala resisted oxidative stress generated during the course of hyperglycemia by significantly increasing the activity of super oxide dismutase and Catalase $(p \leq 0.001)$ and the level of reduced glutathione $(\mathrm{p} \leq 0.001)$. Protective effect on DNA was accessed through significant reduction in the comet tail length $(\mathrm{p} \leq 0.001)$.

Conclusions: 'Triphala' ameliorated not only the oxidative stress but also normalized glucose and lipid homeostasis in subjects with impaired glucose and T2DM.
\end{abstract}

Keywords: Type 2 diabetes, impaired glucose tolerance, Lipid metabolism, Glucose metabolism, Oxidative stress, Antioxidants, Ayurvedic formulations

\section{Introduction}

Type 2 Diabetes mellitus (T2DM) is characterised as a metabolic disorder as it alters both glucose and lipid homeostasis $(1,2)$. Globally, diabetic population outnumber owing to high degree of genetic predisposition and physical inactivity, characterised by high abdominal adiposity, body fat percentage and level of insulin resistance $(3,4)$. The most common alterations in lipid profile in T2DM involve an elevation in plasma triglyceride (TG) and Low density lipoprotein cholesterol (LDL-C) concentrations, and low levels of High density lipoprotein cholesterol (HDL-C) $(5,6,7)$. Hypertriglyceridemia contributes significantly to the

\section{*Corresponding Author:}

\section{Prasad GBKS}

School of Studies in Biochemistry,

Jiwaji University,

Gwalior-474011, India.

Phone no. 0751-2442794

E.mail: gbksprasad@gmail.com increased risk for premature cardiovascular disease in T2DM (8). Perturbed glucose and lipid homeostasis are manifested as oxidative stress in the insulin dependent as well as insulin independent tissues (9). Development of impaired glucose tolerance (IGT) is the outcome of the cumulative effect of all above mentioned disparities and worsened into the form of fully developed T2DM.

Diabetes Control and Complications Trial (DCCT) and the United Kingdom Prospective Diabetes Study (UKPDS) have demonstrated improved outcomes with early detection and tight control of blood glucose (10, 11). Diabetes Epidemiology: Collaborative analysis of Diagnostic criteria in Europe (DECODE) stated that subjects with IGT have an increased risk for developing T2DM and cardiovascular complications and therefore form an important high-risk group for actions aimed at preventing T2DM (12).

According to WHO, traditional herbal remedies may provide valuable leads for the development of alternative drugs and strategies for T2DM and its related complications (13). Herbs prove good antidiabetic agents as they not only improve glucose and lipid 
metabolism by stimulating insulin release; attenuating the absorption of carbohydrates from the gut but also improve antioxidant status. 'Triphala' is the most commonly used Indian Ayurvedic herbal formulation of the "Rasayana" group, consisting equal parts of three medicinal dried plant fruits Emblica Officinalis Gaertn., Terminalia chebula Retz. and Terminalia bellerica Gaertn. (14). Triphala is reported to exhibit a variety of biological activities, such as anti-cancer, antimutagenic, anti-viral, anti-oxidant and free radical scavenging activities and is reported to be reno- and hepato-protective $(15,16)$. Triphala and its individual components have been shown to prevent hyperglycemia and diabetic cataract $(17,18)$. The present study evaluated the therapeutic potential of 'Triphala' in human subjects with IGT and T2DM.

\section{Materials and Methods \\ Study design and Participants}

This was a unicentre, randomized and prospective study comparing two different modalities, IGT and T2DM subjects. The study was conducted in diabetes clinic run by School of Studies in Biochemistry, Jiwaji University, Gwalior, India, on every sunday under the supervision of an Ayurvedic physician. About 500 T2DM and IGT subjects are registered and regularly attend the camp for monthly check up and follow up. The study was approved by the human ethical committee board of Jiwaji University Gwalior. The study protocol was approved by AYUSH and Institutional Human Ethics Committee.

Selection criteria for the study included the following for the people with T2DM and IGT; age $>40$ years, not on any antihyperglycemic or antioxidant therapy, not taking any lipid lowering therapy. A total of 50 subjects attending the diabetes clinic were selected and registered for the study after monitoring their glycemic status and were categorised to one of the two modalities viz., IGT subjects (FBG: $110-126 \mathrm{mg} / \mathrm{dl}$ and PPBG: $\geq 140 \mathrm{mg} / \mathrm{dl}$ to $\leq 200 \mathrm{mg} / \mathrm{dl}, \mathrm{N}=20$ ) and T2DM (FBG: $\geq 126 \mathrm{mg} / \mathrm{dl}$ and PBG: $\geq 200 \mathrm{mg} / \mathrm{dl}, \mathrm{N}=30$ ) with poor glycemic control based on the criteria for the diagnosis of T2DM and IGT by the WHO. The mean age of the subjects was $54.3 \pm 1.75$ years in T2DM group and 55.1 \pm 2.02 years in IGT group. The duration of diabetes was $4.4 \pm 0.58$ years for T2DM subjects and $3.8 \pm 0.66$ years for IGT subjects. All the subjects were informed of the objectives of the study prior to registration and were asked to give a written informed consent. Other demographic and clinical characteristics of the participating subjects are given in Table 1 . Subjects suffering from any chronic or acute inflammatory illness were excluded from the study.

\section{Preparation of Triphala composition}

Fresh mature fruits of Emblica Officinalis Gaertn. were purchased from local market in the Gwalior and shade dried. Whole dried fruit of
Terminalia chebula Retz. and Terminalia bellerica Gaertn. were purchased from the local market in the Gwalior. The dried fruits were then separately milled to fine powder; the powder of individual components was further mixed in the equal proportion to get the Triphala composition.

\section{Administration of 'Triphala'}

The registered T2DM and IGT subjects were enrolled under Triphala therapy at a dose of 5 gms BD before meal (30 minutes prior) every day with normal water for a period of 12 months. Triphala powder was packaged in the airtight sealed plastic bags and each packet contained 35 gms Triphala powder $(5$ gms BD for 7 days) for the first three months. After three months of weekly follow up, sincere and regular patients were then continued for the next nine months of study and each packet contained 150 gms of Triphala powder (5 gms BD for 30 days) till the study end; medicine did not change during the study period. The participants were provided regular counselling on causes and management of diabetes besides anti diabetic ayurvedic medicines. None of the study subjects were on antioxidant supplementation or lipid lowering or anti-diabetic drugs while taking Triphala. The subjects were advocated to maintain their moderate physical activity and to avoid carbohydrate rich diet during the study period. The subjects were followed up at regular monthly intervals for up to 12 months. The therapeutic efficacy of 'Triphala' was evaluated by monitoring glycemic control and plasma lipid profile at specific intervals during the course of study.

\section{Anthropometric data collection and measurement methods}

Details of ethnic origin and age were directly ascertained from the subjects; waist $(\mathrm{cm})$, at the level of the umbilicus with the patient standing and breathing normally, while weight $(\mathrm{kg})$ with weighing balance and height $(\mathrm{m})$, with scale and metal rule, were measured (in light clothing, without shoes). After 10 minutes rest, systolic (first phase) and diastolic (fifth phase) blood pressures (sBP, dBP) were taken on the dominant arm in a sitting position, using a standard mercury gauge sphygmomanometer.

\section{Collection of blood samples}

Approximately $2.5 \mathrm{ml}$ of venous blood was collected in the morning after 12 hours fast from each subject under study once in the beginning of the study and at monthly intervals during the course of study period. Fasting blood samples were transferred to sterilized centrifuge tubes containing sodium EDTA/ sodium fluoride (for glucose) and allowed to stand for 10 minutes at room temperature and then centrifuged (5000 rpm x $10 \min \times 4^{\circ} \mathrm{c}$ ) to get clear plasma. Plasma samples were stored at $-20^{\circ} \mathrm{C}$ for later analysis. After 
removal of plasma and buffy coat from the whole blood; the red blood cells were suspended in $2 \mathrm{ml}$ normal saline and centrifuged $\left(3000 \mathrm{rpm} \times 10 \mathrm{~min} \times 4^{\circ} \mathrm{C}\right)$ to get cell pellet. The cell pellet was washed thrice with normal saline to get packed cell volume (PCV). Haemolysate was prepared by mixing $1.9 \mathrm{ml}$ of cold distilled water to $0.1 \mathrm{ml}$ of PCV suspension and stored at $4^{\circ} \mathrm{C}$.

\section{Laboratory methods}

Blood glucose concentrations in fasting and postprandial samples were determined by the glucose oxidase and peroxidase method using a commercial kit (Erba diagnostics glucose kit, Mannheim Germany) in the fresh blood samples at monthly intervals. Glycosylated Hemoglobin was measured from fresh blood at 3 monthly intervals by ion exchange resin method. The key lipid profile markers viz. total serum cholesterol (TC) (Cholesterol oxidase- peroxidase method), serum triglyceride (TG) (Glycerol 3 peroxidase method), Serum High Density Lipoprotein Cholesterol (HDL-C) (Polyethylene Glycol Precipitation method), Low Density Lipoprotein Cholesterol (LDL-C) (Freidewald's Formula) and Very Low Density Cholesterol (VLDL-C) (Freidewald's Formula) were assayed using commercial kits ( Ecoline Merck NJ USA) from stored plasma at 4 monthly intervals. Analysis of liver function markers viz., Serum aspartate aminotransferase (AST), Alanine amino transferase (ALT) by Modified International federation of clinical chemistry method and serum Bilirubin by Modified Jendrassik and Grof's method at 4 monthly intervals from stored plasma. Kidney function markers viz., Urea by Glutamate Dehydrogenase kinetic method, uric acid by Uricase Method and creatinine by Alkaline Picrate Method were analyzed in serum samples at 4 monthly intervals from stored plasma. Oxidative stress markers viz., Superoxide dismutase activity and Catalase activity were analysed at 4 monthly intervals from the hemolysate $(19,20)$. Lipid peroxidation and reduced glutathione were estimated by from fresh whole blood. Protein was estimated by the method of Lowry et al (21, 22).

\section{Statistical analysis}

The sample size of at least 20 participants per group provided adequate power to detect a difference. Statistical analysis was performed using one-way ANOVA and comparison of the data was done by Student-Newman-Keuls Method with all pair-wise multiple comparison procedures. The data were expressed as Mean \pm SE. The level of significance was set at $\mathrm{p} \leq 0.05$.

\section{Results}

\section{Baseline characteristics}

Table 1 shows the baseline characteristics of the 50 subjects enrolled in the study which includes 30 T2DM and 20 IGT subjects. FBG and PPBG were significantly higher in T2DM compared to IGT subjects $(p \leq 0.05)$. In addition systolic blood pressure was significantly higher in T2DM subjects $(\mathrm{p} \leq 0.05)$.

Table 1: Baseline characteristic features of subjects with IGT and T2DM

\begin{tabular}{|l|l|l|}
\hline Features & IGT & T2DM \\
\hline Number & 20 & 30 \\
\hline Age (years) & $55.1 \pm 2.02$ & $54.3 \pm 1.75$ \\
\hline Sex (male/female) & $16 / 4$ & $28 / 2$ \\
\hline Weight in (Kg) & $67.8 \pm 2.03$ & $71.2 \pm 2.09$ \\
\hline $\begin{array}{l}\text { Body mass index BMI } \\
\text { (kg/m }{ }^{2} \text { ) }\end{array}$ & $24.8 \pm 0.46$ & $25.6 \pm 0.55$ \\
\hline $\begin{array}{l}\text { Fasting blood glucose } \\
\text { (mg/dl) }\end{array}$ & $124.5 \pm 0.6$ & $172.3 \pm 6.6$ \\
\hline $\begin{array}{l}\text { PP blood glucose } \\
\text { (mg/dl) }\end{array}$ & $168.9 \pm 4.18$ & $272.3 \pm 11.4$ \\
\hline $\begin{array}{l}\text { Systolic blood pressure } \\
\text { (mm Hg) }\end{array}$ & $137.6 \pm 3.21$ & $141.6 \pm 3.17$ \\
\hline $\begin{array}{l}\text { Diastolic blood pressure } \\
\text { (mm Hg) }\end{array}$ & $80.4 \pm 2.58$ & $81.6 \pm 0.99$ \\
\hline $\begin{array}{l}\text { Duration of disease } \\
\text { (years) }\end{array}$ & $3.8 \pm 0.66$ & $4.4 \pm 0.58$ \\
\hline
\end{tabular}

Results: mean values $( \pm$ S.E.M); IGT: Impaired glucose tolerance; T2DM: Type 2 diabetes mellitus.

\section{Glucose metabolism}

Blood glucose, HbAlc variables for month $0,4,8$ and 12 for both the treatment groups are shown in Table 2. Individual group analysis revealed that the baseline FBG and PPBG value were significantly higher in the T2DM compared to the IGT subjects $(p \leq 0.001)$. Triphala therapy significantly reduced the glucose levels in the circulation however in T2DM subjects the reduction in PPBG levels 29.0\% ( $\leq \leq 0.001)$ was more pronounced compared to the FBG $20.9 \%$ ( $\mathrm{p} \leq 0.001)$ by $12^{\text {th }}$ month; however, $50 \%$ and $57 \%$ of this decrease occurred by $4^{\text {th }}$ month in both PPBG and FBG respectively. Similarly, in subjects with IGT the FBG and PPBG levels were significantly reduced by $23.5 \%$ $(\mathrm{p} \leq 0.001)$ and $22.3 \%(\mathrm{p} \leq 0.001)$ by $12^{\text {th }}$ month of Triphala therapy however $57 \%$ and $64 \%$ of this reduction occurred from $4^{\text {th }}$ month onwards in FBG and PPBG respectively. Glycemic level did not affect the blood glucose lowering potential of Triphala as drawn out from the significant reductions in FBG and PPBG in both T2DM and IGT groups from $4^{\text {th }}$ month onwards. $\mathrm{GHb}$ levels showed 22.7\% $(\mathrm{p} \leq 0.001)$ and $18.1 \%$ $(\mathrm{p} \leq 0.001)$ reduction in $\mathrm{T} 2 \mathrm{DM}$ and IGT subjects; however, $41 \%$ and $43 \%$ of this decrease occurred from $4^{\text {th }}$ month onwards indicating that short term administration of Triphala showed good glycemic control in T2DM and IGT subjects respectively. 
Nita Singh et.al., Anti-diabetic and Anti-oxidative effect of Triphala

Table 2: Effect of 12 months of Triphala therapy on blood glucose and HbA1c in subjects with T2DM and IGT.

\begin{tabular}{|l|l|l|l|}
\hline Variable(s) & $\begin{array}{l}\text { Intervals } \\
\text { (months) }\end{array}$ & IGT (n=20) & T2DM (n=30) \\
\hline \multirow{4}{*}{$\begin{array}{l}\text { FBG } \\
\text { (mg/dl) }\end{array}$} & 0 & $124.5 \pm 0.6$ & $172.3 \pm 6.6$ \\
\cline { 2 - 4 } & 4 & $107.9 \pm 4.21^{\mathrm{b}}$ & $151.7 \pm 6.5^{\mathrm{c}}$ \\
\cline { 2 - 4 } & 8 & $107.2 \pm 4.22^{\mathrm{b}}$ & $148.0 \pm 5.3^{\mathrm{c}}$ \\
\cline { 2 - 4 } & 12 & $95.2 \pm 1.79^{\mathrm{a}}$ & $136.2 \pm 5.2^{\mathrm{a}}$ \\
\hline \multirow{3}{*}{$\begin{array}{l}\text { P.P BG } \\
\text { (mg/dl) }\end{array}$} & 0 & $168.9 \pm 4.18$ & $272.3 \pm 11.4$ \\
\cline { 2 - 4 } & 4 & $144.5 \pm 5.49^{\mathrm{b}}$ & $232.8 \pm 12.0^{\mathrm{c}}$ \\
\cline { 2 - 4 } & 8 & $137.9 \pm 5.98^{\mathrm{a}}$ & $214.5 \pm 8.2^{\mathrm{c}}$ \\
\cline { 2 - 4 } & 12 & $131.2 \pm 4.95^{\mathrm{a}}$ & $193.3 \pm 8.0^{\mathrm{a}}$ \\
\hline \multirow{4}{*}{$\begin{array}{l}\text { HbA1c } \\
\text { (\%) }\end{array}$} & 0 & $6.5 \pm 0.22$ & $9.6 \pm 0.35$ \\
\cline { 2 - 4 } & 4 & $6.0 \pm 0.22$ & $8.7 \pm 0.35^{\mathrm{c}}$ \\
\cline { 2 - 4 } & 8 & $5.6 \pm 0.20^{\mathrm{b}}$ & $8.3 \pm 0.39^{\mathrm{c}}$ \\
\cline { 2 - 4 } & 12 & $5.4 \pm 0.21^{\mathrm{a}}$ & $7.4 \pm 0.33^{\mathrm{a}}$ \\
\hline
\end{tabular}

Values are mean $\pm \mathrm{SE} ;{ }^{\mathrm{a}} \mathrm{p} £ 0 \cdot 001,{ }^{\mathrm{b}} \mathrm{p} £ 0 \cdot 01,{ }^{\mathrm{c}} \mathrm{p} £ 0 \cdot 05$ are significantly different from baseline value ( 0 month) by one way ANOVA.

\section{Lipid metabolism}

Analysis of individual group reveals glycemic control was associated with a significant improvement in plasma lipid profile. Fasting plasma TG, TC, LDL-C, levels were significantly higher in T2DM patients than in IGT group and consumption of Triphala led to significant and time dependent improvement (Table 3). By $12^{\text {th }}$ month atherogenic lipids such as TC and LDL-C were significantly reduced by $23.1 \%(\mathrm{p} \leq 0.001)$ and $27.4 \%(\mathrm{p} \leq 0.001)$ respectively in $\mathrm{T} 2 \mathrm{DM}$ subjects; however $28.3 \%$ and $27.4 \%$ of this reduction was observed by $4^{\text {th }}$ month, indicative of effectiveness of long term administration of Triphala in the management atherogenic lipids in subjects with T2DM. By $12^{\text {th }}$ month subjects with IGT showed $21 \%(\mathrm{p} \leq 0.001)$ and $36.2 \%(\mathrm{p} \leq 0.001)$ reduction in TC and LDL-C levels; however, $54 \%$ and $50 \%$ decrease of this value was observed in $4^{\text {th }}$ month, indicative of effectiveness of short term administration of Triphala in subjects with IGT. HDL-C is significantly increased by $21.1 \%$ $(\mathrm{p} \leq 0.05)$ and $20.2 \%(\mathrm{p} \leq 0.05)$ in T2DM and IGT group; however, $32 \%$ and $31 \%$ of this increase was observed in $4^{\text {th }}$ month. The total population of T2DM and IGT on Triphala displayed a marked reduction in the mean total plasma TG by $25.9 \%(\mathrm{p} \leq 0.05)$ and $22.1 \%(\mathrm{p} \leq 0.05)$ in 12 months; however, $29.4 \%$ and $32 \%$ of this decrease was observed in $4^{\text {th }}$ month. The data indicates that long term Triphala therapy was beneficial for both IGT and T2DM.
Table 3: Effect of Triphala therapy on Lipid profile in subjects with T2DM and IGT.

\begin{tabular}{|c|c|c|c|}
\hline Variable(s) & $\begin{array}{l}\text { Intervals } \\
\text { (months) }\end{array}$ & IGT $(n=20)$ & $\begin{array}{l}\text { T2DM } \\
(n=30)\end{array}$ \\
\hline \multirow{4}{*}{$\begin{array}{l}\text { TC } \\
\text { (mg/dl) }\end{array}$} & 0 & $174.7 \pm 4.65$ & $191.8 \pm 6.84$ \\
\hline & 4 & $155.0 \pm 5.34^{b}$ & $179.3 \pm 6.60$ \\
\hline & 8 & $149.7 \pm 4.25^{\mathrm{b}}$ & $160.4 \pm 5.27^{\mathrm{a}}$ \\
\hline & 12 & $138.0 \pm 5.41^{\mathrm{a}}$ & $147.4 \pm 5.35^{\mathrm{a}}$ \\
\hline \multirow{4}{*}{$\begin{array}{l}\text { TG } \\
(\mathrm{mg} / \mathrm{dl})\end{array}$} & 0 & $141.0 \pm 9.76$ & $158.9 \pm 10.71$ \\
\hline & 4 & $130.9 \pm 9.63$ & $146.7 \pm 10.68$ \\
\hline & 8 & $114.6 \pm 9.45^{\mathrm{c}}$ & $133.3 \pm 10.94^{\mathrm{c}}$ \\
\hline & 12 & $109.7 \pm 9.00^{\mathrm{c}}$ & $117.6 \pm 10.18^{\mathrm{c}}$ \\
\hline \multirow{4}{*}{$\begin{array}{l}\text { HDL-C } \\
\text { (mg/dl) }\end{array}$} & 0 & $36.7 \pm 2.59$ & $35.8 \pm 2.24$ \\
\hline & 4 & $39.0 \pm 2.76$ & $37.2 \pm 2.36$ \\
\hline & 8 & $41.8 \pm 3.02$ & $38.5 \pm 2.09$ \\
\hline & 12 & $46.1 \pm 2.70^{\mathrm{c}}$ & $44.6 \pm 2.0^{\mathrm{c}}$ \\
\hline \multirow{4}{*}{$\begin{array}{l}\text { LDL-C } \\
\text { (mg/dl) }\end{array}$} & 0 & $109.7 \pm 5.59$ & $125.2 \pm 6.67$ \\
\hline & 4 & $89.7 \pm 6.53^{\mathrm{c}}$ & $112.7 \pm 6.25$ \\
\hline & 8 & $84.9 \pm 5.34^{b}$ & $95.2 \pm 4.81^{\mathrm{a}}$ \\
\hline & 12 & $69.9 \pm 5.79^{\mathrm{a}}$ & $79.6 \pm 4.85^{\mathrm{a}}$ \\
\hline \multirow{4}{*}{$\begin{array}{l}\text { VLDL-C } \\
\text { (mg/dl) }\end{array}$} & 0 & $28.2 \pm 1.95$ & $31.7 \pm 2.14$ \\
\hline & 4 & $26.2 \pm 1.92$ & $29.3 \pm 2.13$ \\
\hline & 8 & $22.9 \pm 1.89^{c}$ & $26.6 \pm 2.18^{c}$ \\
\hline & 12 & $21.9 \pm 1.80^{c}$ & $23.5 \pm 2.03^{\mathrm{c}}$ \\
\hline
\end{tabular}

Values are mean $\pm \mathrm{SE} ;{ }^{\mathrm{a}} \mathrm{p} £ 0 \cdot 001,{ }^{\mathrm{b}} \mathrm{p} £ 0 \cdot 01,{ }^{\mathrm{c}} \mathrm{p} £ 0 \cdot 05$ are significantly different from baseline value ( 0 month) by one way ANOVA.

\section{Alleviation of Oxidative stress}

The activity of antioxidant enzymes viz., SOD and CAT were significantly increased by $31.3 \%(\mathrm{p} \leq 0.001)$ and $34.2 \%(p \leq 0.001)$ in T2DM subject; however, $30.4 \%$ and $45.6 \%$ of this increase was observed in $4^{\text {th }}$ month of Triphala therapy. IGT subjects showed 33.6\% $(\mathrm{p} \leq 0.001)$ and $37 \%(p \leq 0.001)$ increase in the activity of SOD and CAT in 12 months however $31 \%$ and $40 \%$ of this increase was observed in $4^{\text {th }}$ month respectively. By $12^{\text {th }}$ month the level of GSH was increased significantly in both T2M and IGT subjects by $34.5 \%(\mathrm{p} \leq 0.001)$ and $33.7 \%(\mathrm{p} \leq 0.001)$ respectively, by $4^{\text {th }}$ month $33.7 \%$ of this increase was observed in both T2DM and IGT subjects. TBARS levels were significantly reduced by $25.5 \%(p \leq 0.001)$ and $30 \%(p \leq 0.01)$ in T2DM and IGT subjects respectively by $12^{\text {th }}$ month, however $26 \%$ and $28 \%$ of this decrease was observed in $4^{\text {th }}$ month of Triphala therapy. Triphala therapy retrieved the oxidative damage of DNA quantitatively as evident from the significant reductions in the comet tail length by 
International Journal of Ayurvedic Medicine, 2015, 6(3), 212-219

$21.1 \%(\mathrm{p} £ 0 \cdot 005)$ in T2DM and 26\% (p£0.001) in IGT subjects respectively. Hence the results indicate that short term administration of an antioxidant rich natural therapy like Triphala can significantly improve the antioxidant status.

Table 4: Effect of Triphala therapy on oxidative stress markers markers.

\begin{tabular}{|c|c|c|c|}
\hline Variable(s) & $\begin{array}{l}\text { Intervals } \\
\text { (months) }\end{array}$ & $\begin{array}{l}\text { IGT } \\
(\mathbf{n}=\mathbf{2 0})\end{array}$ & $\begin{array}{l}\text { T2DM } \\
(\mathrm{n}=30)\end{array}$ \\
\hline \multirow{4}{*}{$\begin{array}{l}\text { Superoxide } \\
\text { Dismutase } \\
\text { (SOD) } \\
\text { (Unit/min/ } \\
\text { mg of } \\
\text { protein) }\end{array}$} & 0 & $0.83 \pm 0.04$ & $0.76 \pm 0.02$ \\
\hline & 4 & $0.91 \pm 0.04$ & $0.84 \pm 0.03^{\mathrm{c}}$ \\
\hline & 8 & $1.10 \pm 0.05^{\mathrm{a}}$ & $0.97 \pm 0.05^{\mathrm{c}}$ \\
\hline & 12 & $1.25 \pm 0.05^{\mathrm{a}}$ & $1.11 \pm 0.06^{\mathrm{a}}$ \\
\hline \multirow{4}{*}{$\begin{array}{l}\text { Catalase } \\
(\text { CAT) } \\
(\mu \mathrm{mole} / \mathrm{min} / \\
\mathrm{mg} \\
\text { protein) }\end{array}$} & 0 & $6.7 \pm 0.32$ & $6.5 \pm 0.19$ \\
\hline & 4 & $7.7 \pm 0.34^{\mathrm{c}}$ & $7.5 \pm 0.26^{\mathrm{c}}$ \\
\hline & 8 & $9.2 \pm 0.45^{b}$ & $8.2 \pm 0.39^{\mathrm{a}}$ \\
\hline & 12 & $10.6 \pm 0.26^{\mathrm{a}}$ & $9.8 \pm 0.36^{\mathrm{a}}$ \\
\hline \multirow{4}{*}{$\begin{array}{l}\text { Reduced } \\
\text { glutathione } \\
\text { (GSH) (mg/ } \\
\text { ml) }\end{array}$} & 0 & $1.9 \pm 0.13$ & $1.8 \pm 0.11$ \\
\hline & 4 & $2.2 \pm 0.18^{\mathrm{c}}$ & $2.0 \pm 0.15$ \\
\hline & 8 & $2.6 \pm 0.21^{\mathrm{c}}$ & $2.5 \pm 0.15^{b}$ \\
\hline & 12 & $3.1 \pm 0.1^{\mathrm{a}}$ & $2.8 \pm 0.12^{\mathrm{a}}$ \\
\hline \multirow{4}{*}{$\begin{array}{l}\text { Thio- } \\
\text { barbeturic } \\
\text { acid reactive } \\
\text { substance } \\
\text { (TBARS) } \\
\text { (moles of } \\
\text { MDA / ml } \\
\text { blood) }\end{array}$} & 0 & $368.5 \pm 22.02$ & $451.5 \pm 18.04$ \\
\hline & 4 & $337.0 \pm 23.11^{\mathrm{c}}$ & $421.3 \pm 16.48$ \\
\hline & 8 & $301.1 \pm 21.19^{c}$ & $371.1 \pm 16.27^{b}$ \\
\hline & 12 & $257.7 \pm 16.99^{b}$ & $336.1 \pm 16.27^{\mathrm{a}}$ \\
\hline
\end{tabular}

Values are mean $\pm \mathrm{SE} ;{ }^{\mathrm{a}} \mathrm{p} £ 0 \cdot 001,{ }^{\mathrm{b}} \mathrm{p} 0 \cdot 01,{ }^{\mathrm{c}} \mathrm{p} £ 0 \cdot 05$ are significantly different from baseline value ( 0 month) by one way ANOVA.

Table 5: Effect of Triphala therapy on oxidative DNA damage after 12 months

\begin{tabular}{|l|l|l|l|}
\hline Variable(s) & Intervals & $\begin{array}{l}\text { IGT } \\
(\mathbf{n = 2 0})\end{array}$ & $\begin{array}{l}\text { T2DM } \\
(\mathbf{n = 3 0})\end{array}$ \\
\hline $\begin{array}{l}\text { Comet tail } \\
\text { length } \\
\text { (arbitrary unit) }\end{array}$ & 0 month & $4.6 \pm 1.6$ & $5.2 \pm 1.1$ \\
\cline { 2 - 4 } & 12 months & $3.4 \pm 1.02^{\mathrm{b}}$ & $4.1 \pm 1.07^{\mathrm{a}}$ \\
\hline
\end{tabular}

Values are mean $\pm \mathrm{SE} ;{ }^{\mathrm{a}} \mathrm{p} £ 0 \cdot 001,{ }^{\mathrm{b}} \mathrm{p} £ 0.01,{ }^{\mathrm{c}} \mathrm{p} £ 0.05$ are significantly different from baseline value ( 0 month) by one way ANOVA.
Figure 1: Assessment of DNA damage through alkaline comet assay in Triphala administered subjects. Ethedium bromide stained representative pseudo colored images are shown for IGT (A) and T2DM (C) respectively before Triphala Regimen. Intense red color represents intact DNA, while blurred tail like structure shows increasing level of DNA fragmentation. Images (B) are (D) are captured under identical magnification

(10x) to show the relative recovery after Triphala therapy respectively.
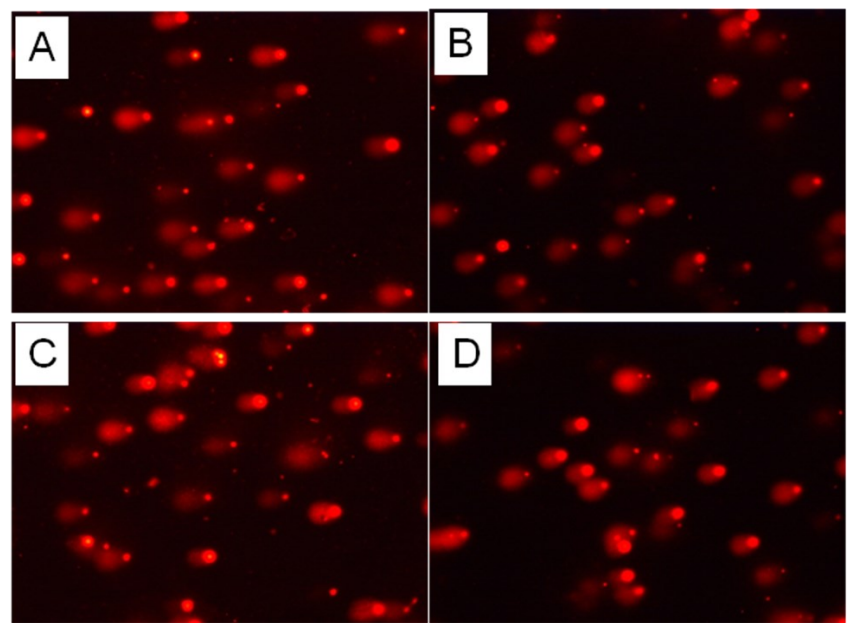

\section{Antitoxic effect on Liver and kidney}

The liver function markers viz., Bilirubin, SGOT and SGPT were significantly reduced by $22.2 \%$ $(p \leq 0.001), \quad 22.1 \% \quad(p \leq 0.05) \quad$ and $\quad 29 \% \quad(p \leq 0.01)$ respectively in T2DM subjects, similarly IGT subjects showed $25 \%(p \leq 0.001), 24 \%(p \leq 0.05)$ and $28 \%(p \leq 0.01)$ reduction in the following liver function markers respectively.

Kidney function markers viz., creatinine, urea and uric acid were significantly reduced by $27 \%(\mathrm{p} \leq 0.001)$, $29 \%(\mathrm{p} \leq 0.001)$ and $24 \%(\mathrm{p} \leq 0.001)$ in T2DM subjects. Similarly, IGT subjects showed significant reduction of $24 \% \quad(p \leq 0.01), 25 \% \quad(p \leq 0.001)$ and $26 \% \quad(p \leq 0.001)$ respectively in 12 months of Triphala therapy. Results indicated antitoxic effect of long term administration of Triphala on liver and kidney.

Table 6: Effect of Triphala therapy on Liver and kidney function markers.

\begin{tabular}{|l|l|l|l|}
\hline Variable(s) & $\begin{array}{l}\text { Intervals } \\
(\text { months) }\end{array}$ & IGT $(\mathbf{n = 2 0})$ & $\begin{array}{l}\text { T2DM } \\
(\mathbf{n}=\mathbf{3 0})\end{array}$ \\
\hline \multirow{4}{*}{$\begin{array}{l}\text { AST } \\
(\mathbf{U} / \mathbf{I})\end{array}$} & 0 & $27.2 \pm 1.83$ & $26.6 \pm 1.46$ \\
\cline { 2 - 4 } & 4 & $25.0 \pm 1.69$ & $22.9 \pm 1.73^{\mathrm{c}}$ \\
\cline { 2 - 4 } & 8 & $23.1 \pm 1.90$ & $24.1 \pm 1.66^{\mathrm{c}}$ \\
\cline { 2 - 4 } & 12 & $20.7 \pm 1.76^{\mathrm{c}}$ & $20.7 \pm 1.42^{\mathrm{c}}$ \\
\hline \multirow{4}{*}{$\begin{array}{l}\text { ALT } \\
(\mathbf{U} / \mathbf{I})\end{array}$} & 0 & $26.4 \pm 1.63$ & $28.4 \pm 1.42$ \\
\cline { 2 - 4 } & 4 & $24.1 \pm 1.45^{\mathrm{c}}$ & $23.4 \pm 1.60^{\mathrm{c}}$ \\
\cline { 2 - 4 } & 8 & $22.5 \pm 1.51^{\mathrm{c}}$ & $22.8 \pm 1.60^{\mathrm{c}}$ \\
\cline { 2 - 4 } & 12 & $18.9 \pm 1.33^{\mathrm{b}}$ & $20.1 \pm 1.10^{\mathrm{b}}$ \\
\hline
\end{tabular}


Nita Singh et.al., Anti-diabetic and Anti-oxidative effect of Triphala

\begin{tabular}{|c|c|c|c|}
\hline \multirow{4}{*}{$\begin{array}{l}\text { Bilirubin } \\
\text { (mg/dl) }\end{array}$} & 0 & $0.8 \pm 0.03$ & $0.96 \pm 0.03$ \\
\hline & 4 & $0.75 \pm 0.03$ & $0.81 \pm 0.02^{\mathrm{a}}$ \\
\hline & 8 & $0.66 \pm 0.03^{c}$ & $0.76 \pm 0.03^{\mathrm{a}}$ \\
\hline & 12 & $0.6 \pm 0.03^{\mathrm{a}}$ & $0.75 \pm 0.03^{\mathrm{a}}$ \\
\hline \multirow{4}{*}{$\begin{array}{l}\text { Urea } \\
(\mathrm{mg} / \mathrm{dl})\end{array}$} & 0 & $33.3 \pm 1.12$ & $35.2 \pm 1.15$ \\
\hline & 4 & $30.0 \pm 1.46$ & $30.7 \pm 1.01^{b}$ \\
\hline & 8 & $28.3 \pm 1.46^{\mathrm{c}}$ & $29.9 \pm 1.07^{\mathrm{b}}$ \\
\hline & 12 & $24.9 \pm 1.06^{\mathrm{a}}$ & $25.0 \pm 1.02^{\mathrm{a}}$ \\
\hline \multirow{4}{*}{$\begin{array}{l}\text { Uric acid } \\
\text { (mg/dl) }\end{array}$} & 0 & $5.3 \pm 0.21$ & $5.4 \pm 0.17$ \\
\hline & 4 & $4.6 \pm 0.17^{\mathrm{c}}$ & $4.8 \pm 0.16^{\mathrm{c}}$ \\
\hline & 8 & $4.2 \pm 0.17^{\mathrm{a}}$ & $4.4 \pm 0.14^{\mathrm{b}}$ \\
\hline & 12 & $3.9 \pm 0.16^{\mathrm{a}}$ & $4.1 \pm 0.16^{\mathrm{a}}$ \\
\hline \multirow{4}{*}{$\begin{array}{l}\text { Createnine } \\
(\mathrm{mg} / \mathrm{dl})\end{array}$} & 0 & $1.04 \pm 0.06$ & $1.09 \pm 0.04$ \\
\hline & 4 & $0.96 \pm 0.05$ & $0.95 \pm 0.04^{\mathrm{c}}$ \\
\hline & 8 & $0.93 \pm 0.04$ & $0.91 \pm 0.04^{c}$ \\
\hline & 12 & $0.79 \pm 0.04^{b}$ & $0.79 \pm 0.04^{\mathrm{a}}$ \\
\hline
\end{tabular}

Values are mean $\pm \mathrm{SE} ;{ }^{\mathrm{a}} \mathrm{p} £ 0 \cdot 001,{ }^{\mathrm{b}} \mathrm{p} £ 0 \cdot 01,{ }^{\mathrm{c}} \mathrm{p} £ 0 \cdot 05$ are significantly different from baseline value ( 0 month) by one way ANOVA.

\section{Discussion}

Diabetes mellitus is the World's largest growing metabolic disorder, goes un-noticed in the form of prediabetics (IGT), presenting all the aetiologies of T2DM, thus forms a major risk group aimed at preventing T2DM. Traditional plant medicines are being used in place of costlier modern medicines throughout the world for better management of T2DM and IGT (23). Thus in the present study antioxidant rich ayurvedic formulation Triphala was validated for its antihyperglycemic, antihyperlipidemic and antioxidant potential in human T2DM and IGT subjects.

Oral administration of Triphala to humans T2DM and IGT subjects for 12 months resulted in a significant reduction in both FBG and PPBG levels however; the reduction in PPBG was more pronounced compared to FBG in IGT groups. The improvement in glycemic levels of IGT group due to Triphala can help control the progression of T2DM. Treatment with Triphala significantly decreased the levels glycosylated haemoglobin. The proportion of haemoglobin that is glycosylated is known to increase substantially in conditions of sustained hyperglycaemia $(24,25)$. The significant reduction in glycemic level with Triphala could be due to the optimization of activities of carbohydrate metabolizing enzymes, increase in carbohydrate absorption time and stimulation of insulin release from the pancreatic beta cells $(26,27)$. Glucose lowering effects of Triphala have been reported earlier in STZ induced diabetic rats $(27,28,29)$.
The American Heart Association emphasizes the role of lipid abnormalities in $\operatorname{T} 2 \mathrm{DM}(30,31)$. In the present study dyslipiemia was recorded in both T2DM and IGT though the increase in triglycerides (TG) and low-density lipoprotein cholesterol (LDL-C) levels and decrease high-density lipoprotein cholesterol (HDL-C) was more in T2DM. We observed the percentage improvement in lipid profile owing to Triphala was statistically significant in both IGT and T2DM subjects. Both treatment groups with reduction in levels of plasma TG and TC displayed a significant increase in the levels of the HDL fraction on Triphala therapy. The decreased serum HDL-C was reversed towards normalization after Triphala therapy. The beneficial effect of Triphala on HDL $-\mathrm{C}$ is well recognised and likely to be clinically relevant. The progressive shift of LDL profile towards normal with decrease in fasting TG and TC levels observed in T2DM resulted perhaps from a specific decrease in plasma levels of glucose fractions by Triphala. The blood glucose and lipid lowering activity of Triphala demonstrated in IGT subjects in this study may represent a novel and important preventive approach in delaying the onset of diabetes mellitus and CVD; however the long term administration of Triphala proved effective in addressing dyslipidemia. The blood lipid lowering effects of Triphala are attributed to Terminalia chebula Retz. $(32,33)$

Results of the present study indicated that Triphala besides antihyperglycemic, antihyperlipidemic possesses a very good antioxidant property. Triphala administration attenuated the diabetes induced depletion of antioxidants. Triphala not only significantly increased the activity of antioxidant enzymes viz., SOD and CAT but also increased the levels of reduced glutathione in both the treatment groups. The observed improvement in the level of these antioxidants after the administration of Triphala in hyperglycemia may be due to the direct reaction of gallic acid, ascorbic acid and flavonoids in Triphala with the free radicals generated and converting the reactive oxygen free radicals to non-reactive products $(34,35)$. Lipid peroxidation is regarded as one of the basic mechanism of tissue damage caused by free radicals. Triphala administration significantly reduced the levels of LPO in both T2DM and IGT groups. This scrutiny reveals that Triphala is able to quench the LPO chain and is capable to shield the membrane from free radical caused injuries. Triphala therapy significantly protected the DNA from oxidative damage in both T2DM and IGT subjects. This present study thus indicates the antioxidant potency of the drug.

To conclude, the results of the present study have empirically indicated that Triphala has protective role in IGT and was effective in the treatment of T2DM. A consistent decrease in the blood glucose level by Triphala in diabetic patients and parallel improvement in lipid profile makes it a good choice as an alternative antidiabetic drug which is non habit forming and cheap as alternatives are needed due to side effects of several 
allopathic drugs and development of resistance to currently used.

There are clearly some limitations of this study. First, this is an ancillary study that is dependent on the main study for the study design. Second the number of patients in each group is small. Though the study was powered for antihyperglycemic potential of the drug under observation, a very important parameter i.e. measurement of insulin release is lacking.

\section{Acknowledgements}

The authors are thankful to all subjects who volunteered to participate in the study. The Authors are thankful to Dr. Harimohan Goswami, Ayurvedic physician for his constant guidance and supervision. The authors sincerely acknowledge Prof. Sangeeta Shukla, Vice Chancellor of Jiwaji University for her keen interest in the study and encouragement.

\section{Funding source}

The authors are thankful the funding source (AYUSH) New Delhi for the necessary financial support to investigate the potential of 'Triphala-411' formulation for its prophylactic and therapeutic potential in T2DM with No. F.NO.Z.31014/02/2009/ EMR-CCARS.

\section{Conflict of interest}

The authors declare that there is no conflict of interest associated with this manuscript.

\section{References}

1. Jürgens HS, Neschen $\mathrm{S}$, Ortmann $\mathrm{S}$ et al. Development of diabetes in obese, insulin-resistant mice: essential role of dietary carbohydrate in beta cell destruction. Diabetologia 2007; 50: 1481-1489.

2. Leahy JL, Bonner-Weir S, Weir G: Beta-cell dysfunction induced by chronic hyperglycemia. Current ideas on mechanism of impaired glucoseinduced insulin secretion. Diabetes Care 1992; 15: $442-455$.

3. Garcia MJ, Mc Namara PM, Gordon T, Kannel WB: Morbidity and mortality in diabetics in the Framingham population, Sixteen year follow-up study. Diabetes 1974; 23: 105-11.

4. Haffiner SM, Lehto S, Ronnemaa T, Pyorala K, Laakso M: Mortality from coronary heart disease in subjects with type 2 diabetes and in non-diabetic subjects. NEJM 1998; 339: 229-34.

5. De Man FH, Cabezas MC, Van Barlingen VHH, Erkelens DW, de Bruin TW: Triglyceride-rich lipoproteins in non-insulin-dependent diabetes mellitus: post-prandial metabolism and relation to premature atherosclerosis. Eur J Clin Inv 1996; 26: $89-108$.

6. Martinez, Castelao A, Ramos R, Gonzalez MT, Castineiras MJ: Dyslipidemia and Cardiovascular risk factors in type 2 diabetes mellitus patients with associated diabetic nephropathy. Nefrologia 2002; 22(1): 51-58.

7. Rosenson RS: HDL-C and the diabetic patient: target for therapeutic intervention. Diab Res Clin Prac 2005; 68(2): S36-S42.

8. Guérin M, Goff WL, Lassel TS, Tol AV, Steiner G, Chapman MJ: Proatherogenic Role of Elevated CE Transfer From HDL to VLDL1 and Dense LDL in Type 2 Diabetes: Impact of the Degree of Triglyceridemia. Arterioscler Thromb Vasc Biol 2001; 21: 282-28,

9. Evans JL, Goldfine ID, Maddux BA, Grodsky GM: Oxidative Stress and Stress-Activated Signaling Pathways: A Unifying Hypothesis of Type 2 Diabetes. Endocr Rev 2002; 23: 599-622.

10. DCCT Research Group: The effect of intensive treatment of diabetes on the development and progression of long-term complications in insulin dependent diabetes mellitus. NEJM 1993; 329: 977986.

11. UK Prospective Diabetes Study (UKPDS) Group: Intensive blood-glucose control with sulphonylureas or insulin compared with conventional treatment and risk of complications in patients with type 2 diabetes (UKPDS 33). Lancet 1998; 352:837-853.

12. The DECODE study group: Glucose tolerance and mortality: comparison of WHO and American diabetes association diagnostic criteria. Lancet 1999; 354, 617-621.

13. World Health Organization. WHO Expert Committee on Diabetes Mellitus: Second Report. Tech Rep S 1998; 646.

14. Jagetia GC, Baliga MS, Malagi KJ, Sethukumar KM: The evaluation of the radioprotective effect of Triphala (an Ayurvedic rejuvenating drug) in the mice exposed to gamma-radiation. Phytomedicine 2002; 9: 99-108.

15. Rao NK, Nammi S: Antidiabetic and renoprotective effects of the chloroform extract of Terminalia chebula Retz. seeds in streptozotocin-induced diabetic Rats. BMC Comp Alt Med 2006; 6: 17.

16. Tasduk SS, Singh AK, Salti NK, Gupta DK, Suri K: Terminalia chebula fruits prevent liver toxicity caused by sub-chronic administration of refampicin, isoniazid and pyrazinamide (PZA) in combination. Human Exp Toxicol 2006; 25(3): 11-18.

17. Suryanarayana P, Kumar PA, Saraswat M, Petrash MJ, Reddy GB: Inhibition of aldose reductase by tannoid principles of Emblica officinalis: Implications for the prevention of sugar cataract. Mol Vis 2004; 10: 148-54.

18. Reddy GB, Satyanarayana A, Balakrishna N et al. Erythrocyte aldose reductase activity and sorbitol levels in diabetic retinopathy. Mol Vis 2008; 14: 593 $-601$.

19. Kakkar P, Das B, Viswanathan P: A modified method for assay of superoxide dismutase. Indian $J$ Biochem Bio 1984; 21: 131-132. 
20. Sinha AK: Colorimetric assay of Catalase. Anal Biochem 1972; 47: 389-394.

21. Ohkawa H, Ohishi N, Yagi K: Assay for lipid peroxides in animal tissues by thiobarbituric acid reaction. A nal Biochem 1979; 95: 351-358.

22. Ellman GL: Tissue sulfhydryl groups. Arch Biochem Biophys 1959; 82: 70-77.

23. Bailey CJ, Day C: Traditional plant medicines as treatments for diabetes. Diabetes care 1989; 12: 553 -564 .

24. Rahbar S: An abnormal hemoglobin in red cells of diabetics. Clinica chimica acta 1968; 22: 296-298.

25. Triivelli LA, Ranney HM, Lai HT: Hemoglobin components in patients with diabetes mellitus. NEJM 1971; 284: 353-357.

26. Senthilkumar GP, Arulselvan P, Sathishkumar D, Subramanian SP: Anti-Diabetic activity of fruits on Terminalia chebula on Streptozotocin induced diabetic rats. J Health Sci 2006; 52: 281-289.

27. Senthilkumar GP, Subramanian SP: Biochemical studies on the effect of Terminalia chebula on the levels of glycoproteins in streptozotocin-induced experimental diabetes in rats. J Appl Biomed 2008; 6: $105-115$.

28. Murali YK, Chandra R, Murthy PS: Antihyperglycemic effect of water extract of dry fruits of terminalia chebula in experimental diabetes mellitus. Indian J Clin Biochem 2004; 19 (2): 202204.
29. Sabu MC, Kuttan R: Antidiabetic and antioxidant activity of terminalia belerica. Indian $J$ Exp Biol 2008; 47: 270-275.

30. Grundy SM, Benjamin IJ, Burke GL et al. Diabetes and cardiovascular disease: a statement for healthcare professionals from the American Heart Association. Circulation 1999; 100, 1134-1146.

31. Boizel R, Benhamou PY, Lardy B, Laporte F, Foulon T, Halimi S: Ratio of Triglycerides to HDL Cholesterol Is an Indicator of LDL Particle Size in Patients With Type 2 Diabetes and Normal HDL Cholesterol Levels. Diabetes care 2000 ; 23(11).

32. Saravanan S, Srikumar R, Manikandan S, Parthasarathy NJ, Sheela DR : Hypolipidemic effect of triphala in experimentally induced hypercholesteremic rats. Pharmaceut Soc Jpn 2007 ; 127: $385-8$.

33. Thakur CP, Thakur B, Singh S, Sinha PK, Sinha SK : The Ayurvedic medicines Haritaki, Amla and Bahira reduce cholesterol-induced atherosclerosis in rabbits. Int J Cardiol 1988; 21: 16775.

34. Bhattacharya SK, Bhattacharya A, Sairam K, Ghosal S: Effect of bioactive tannoid principles of Emblica officinalis on ischemia reperfusion- induced oxidative stress in rat heart. Phytomedicine 2002; 9: 171-174.

35. Anila L, Vijayalakshmi NR: Flavonoids from Emblica officinalis and Mangifera indica effectiveness for dyslipidemia. J Ethnopharmacol 2002; 79: 81-7. 